\title{
Police Role In The Effort Management And Control The Fight Between Youth In Making Public Order In The Blora Regency
}

\begin{abstract}
Zaenul Arifin $^{1}$ and Sukarmi ${ }^{2}$
Abstract. Group fights criminal acts defined as crimes of violence together as provided for in Article 170 of the Criminal Code. Data from Blora Regency police indicate that a fight between youth always the case in every year in the Blora Regency. This study aims to determine the role of the police in handling and overcoming a fight between youth, barriers and solutions in realizing the public order in Blora. The method used is the juridical sociological, descriptive analytical research specifications. The data used are primary data and secondary data, while the data collection method is field studies and literature. Using data analysis methods of qualitative analysis. The analysis used as knife crime prevention theory, theory and the theory of the role of law enforcement. The results showed that the role of the police in handling and overcoming a fight between youth in realizing the public order in Blora is through the efforts of non penal (preventive) and attempts penal (repressive). Barriers arising in the treatment and prevention of fights between youth to realize the public order in Blora is the number of police personnel limited, the police difficult to present witnesses so that not all the perpetrators can be arrested, the third party to interfere in the settlement of the problem, and the lack of awareness Public.

Keywords: Role; National Police; Prevention; Fights Between Youth.
\end{abstract}

\section{Introduction}

The criminal action fights groups in the Criminal Code defined as a criminal act of violence together as provided in Article 170 which states that whoever openly and with power shared use violence against people or property, punishable by a maximum imprisonment of five years and six months. If these actions resulted in injuries then the punishment shall be imprisonment of seven years, if it resulted in the serious injury shall be punished by a maximum imprisonment of nine years, and if it resulted in death shall be punished by a maximum imprisonment of twelve years.

Fights involving some people also regulated in the Criminal Code, Article 358 of the Criminal Code on assault stating that they were intentionally participated in the attack or fight in which involved several people, in addition to the responsibility of each to what is typically carried out by him, threatened: ${ }^{3}$

Number 1. with a maximum imprisonment of two years and eight months, if as a result of the attack or fight was no serious injuries;

$2^{\text {nd }}$. with a maximum imprisonment of four years, if no one died as a result.

Based on the formulation of Article 170 of the Criminal Code and Article 358 of the Criminal Code, fights a group / bulk are acts of violence or participated in attacks both against people and goods together. In this case Article 358 of the Criminal Code

\footnotetext{
${ }^{1}$ Student of Master of Law, Universitas Islam Sultan Agung Semarang and Police member, email: zaenularifin47@yahoo.com

${ }^{2}$ Lecturer of Faculty of Law, Sultan Agung Islamic University (UNISSULA), Semarang

${ }^{3}$ EM Soterio Maudoma, Use of Force In Together In Article 170 and Article 358 of the Criminal Code, Lex crimen, Vol.IV / 6 / Aug / 2015, p.67
} 
threatens offenders with imprisonment up to four years, if no one died as a result.

Fights between youth people always creates a tense atmosphere and ended with the fall of injuries to deaths and material losses are not small. The intensity of violence and mass action in the community is not showing signs of decreasing. Such a phenomenon is of course necessary scrutiny and attention, because can raise concerns and anxiety for the people. For the government in this case law enforcement officials and community leaders should always cooperate and coordinate to solve the root of the problem.

Data from Blora Regency police indicate that a fight between youth always the case in every year in the Blora Regency. This was seen in 2018 there were 3 cases of fights, while in 2019 there were 4 cases. One case that occurred a fight between youth fueled by the influence of liquor.

Several attempts have been made to deal and cope with the crime of fighting between the youth both preventive and repressive. Preventive efforts made through socialization and patrols, while the repressive efforts made by the effort of investigation by the police. Police is a tool that plays a role in maintaining state security and public order, enforcing the law, and to provide protection, shelter and services to the community in the context of the maintenance of internal security. Indonesian National Police is the national police unity in carrying out the role as the keeper of security, keepers of public order,

Based on the above, the authors are interested in doing research by taking the title of " Police Role In The Effort Management And Control The Fight Between Youth In Making Public Order In The Blora Regency".

Based on the description of the background described above, then the problem is formulated as follows: How is the role of the police in handling and overcoming a fight between youth in realizing the public order in Blora? What obstacles that arise in the treatment and prevention of fights between youth to realize the public order in Blora and what's the solution?

\section{Research Method}

The method used in this research is empirical juridical approach. Research is descriptive analytical specifications, which provide a clear, detailed and systematic. The data used are primary data and secondary data obtained through field studies and literature. The method of data analysis using qualitative analysis.

\section{Results and Discussion}

\subsection{Role of the Police in Handling and Prevention Efforts of Fights Between Youth in Realizing Public Order in Blora}

Based on the interview Invisible Criminal Police Blora, there are some actions taken by the police in the handling and prevention of fights between youths in Blora, namely in the form of preventive and repressive action. ${ }^{4}$

The role of the police in handling and overcoming a fight between youth through

\footnotetext{
${ }^{4}$ Results of interviews with Herri AKP Dwi Utomo as the Invisible Criminal Police Blora, dated February 5, 2020.
} 
preventive efforts is to optimize the role Bhabinkamtibmas with socialization / counseling in the execution of their duties, securing locations prone to fights between youth people, for example in the event dangdut concert, as well as patrols carried out in the Blora Regency.

Preventive measures taken to prevent the occurrence or onset of a crime for the first time. Crime prevention is better than trying to educate criminals become better return, as the slogan in criminology that efforts need to be considered criminals repair and directed from happening again repeat crimes. Very reasonable when preventive efforts prioritized for preventive measures can be done by anyone without a special skill, and economical.

Basically preventive efforts include activities aimed at preventing the direct of the crime, which includes activities that are expected to contain police hazard, including the activities of community development, which aims to motivate all levels of society in order to participate actively in efforts to prevent, deter and reduce crime.

A repressive measure the actions taken by the police after the crime. Countermeasures to the repressive efforts intended to take action against the perpetrators in accordance with the deeds and fix it back so that the criminals realize that the act of doing is an act of unlawful and harmful to society, so it will not repeat it and others will not do so in view of the sanctions that would be acceptable very heavy.

Repressive efforts made by the police in the handling and prevention of fights between youth people in Blora is with carry out action fights investigation on cases occurring in the community. Before carrying out a series of investigative actions, first conducted an investigation involving members of Opsnal (Criminal members who involving members who served in the field at the time of the fight between the youth), resumed at the stage of investigation of the criminal acts that have occurred.

In the case of a fight between youth, preferably settlement case amicably settlement priority (peace efforts). This is as Putoro Rambe which states that in case of a fight between youth, usually made peace efforts in particular in terms of offender and victim knew each other. But if that is desired by the victim, the case of a fight between youths continued to the stage of the proceedings. ${ }^{5}$

The process of criminal investigations fight between youth is guided by the Code of Criminal Procedure and the implementation of legislation, namely the Regulation of Police No. 6 of 2019 concerning the Crime Investigation. The investigation started after a police report (LP) are accepted. There are two types of police reports under the provisions of Article 3 of the Regulation of Police No. 6 of 2019 concerning the Crime Investigation.

Judging from the theory of crime prevention, the efforts of the Police in the treatment and prevention of fighting between youth in accordance with the theory of crime prevention. This is as stated by Barda Nawari Arief that, countermeasures that all efforts made by any person or government or private institutions aimed seek security, control and welfare in accordance with human rights there. Crime prevention efforts can be broadly divided into two, non penal lines (preventive measures) and penal lines

\footnotetext{
${ }^{5}$ Results of interviews with Bripka Putoro Rambe Police as investigators in Blora, dated February 6, 2020.
} 
(Repressive efforts). ${ }^{6}$

Efforts non penal implemented a series of measures to prevent a fight between youth, while the penal efforts implemented through the judicial process in the event of a fight between youths in Blora.

Handling and control of a fight between youths in Blora in accordance with the theory of law enforcement. As we know that the purpose of law enforcement is the rule of law, achieving legal certainty, and the realization of justice. According Soerjono Soekanto, there are several factors that affect law enforcement, the legal factors alone, law enforcement apparatus, means or facility factors, community factors, and cultural factors. ${ }^{7}$

Judging from the theory of the role, national police efforts in the handling and prevention of fights between youth to realize the public order in accordance role theory. This is as stated by Soerjono Soekanto which states that the role or the role of behavior patterns associated with status or status as a pattern of behavior. If a person is exercising its rights and obligations in accordance with the position then he runs a role. ${ }^{8}$ Police role in the effort of the national police in the handling and prevention of fights between youth to realize the order is expected roles, the role of which is carried out in accordance with the conditions set together. In this case the ranks of the Police in Blora regency duties and obligations in providing shelter and provide a sense to obtain any society based on laws and regulations that already exist including the Penal Code, Criminal Procedure Code, Act No. 2 of 2002 on the Indonesian National Police, and the Police Chief Regulation of the Republic of Indonesia Number 6 of 2019 concerning the Crime Investigation.

Police efforts in addressing and tackling the fight between youths in Blora in the form of preventive and repressive is a form the role as a law creating the legal authorities of public order. This is in line with the provisions of Act No. 2 of 2002 on the Indonesian police stating that the police is one of the functions of state government in maintaining security and public order, law enforcement, protector and steward to the community.

\subsection{The Obstacle In Handling And Countermeasures Fighting Between Youth To Achieve Public Order In Blora And Solutions}

Police efforts in the handling and prevention of fights between youth to realize the public order in Blora sometimes face some obstacles. These barriers include: ${ }^{9}$

- The number of police personnel limited

The handling and control of a fight between youths in the city of Blora hampered by the lack of the number of police personnel. In the case of a fight between youth event dangdut orchestra, the audience more than the police officers on duty guard. Fights between youth involved many people, where there is a little nudge can trigger

\footnotetext{
${ }^{6}$ Barda Nawawi Arif, 2006, Masalah Penegakan Hukum dan Kebijakan Hukum Pidana dalam Penanggulangan Kejahatan, Bandung: Citra Aditya Bakti, p. 49.

${ }^{7}$ Soerjono Soekanto, 1986, Faktor-Faktor yang Mempengaruhi Penegakan Hukum, Jakarta: Rineka Cipta, p. 8

${ }^{8}$ Ibid.

${ }^{9}$ Results of interviews with Herri AKP Dwi Utomo as the Invisible Criminal Police Blora, dated February 5, 2020.
} 
a fight. This resulted Police officer difficulty in handling a fight involving many people remember the number of personnel on duty is very limited. As a result, when the officers managed to break up the fight, the condition of the victim was injured.

To overcome these obstacles Police officers attempted to appeal to the audience stayed on and was not provoked emotions and was involved in the fights. Police officers also went to the location as soon as possible and finish the fight in accordance with the applicable procedures.

- Police difficult to present witnesses so that not all the perpetrators can be arrested

A repressive measure implemented through inquiry and investigation procedures is hampered due to investigators difficulty to produce witnesses. This is because when a fight broke many involved and the officer can not know the actors one by one. For example in the case known that commit acts of violence against the victim is the suspect and also some unknown. Some unknown person has been unable to be questioned as a witness because it was straight away after taking part in beating the victim.

To overcome this, the investigators asked for statements of several people who could serve as witnesses to meet the criteria of sufficient preliminary evidence in the investigation process. Two witnesses is enough be used as guidance for further investigation process.

- The presence of a third party to intervene in problem solving In the fight between the treatment and prevention of youth, there are times when the result was done amicably (peace). This usually occurs when the perpetrator and the victim are still getting to know each other. However, there are third parties who intervened in solving these problems. Such third parties could from relatives of victims who did not receive and complicate the peace efforts. For example, the victim's brother insisted on bringing the case to court, and influence the victim to resolve the issue through the courts. This raises doubts in the victim to make a peace agreement, despite the fact that the victim had intended to peace.

To overcome these obstacles Police attempted to intensive approach to the victim and the perpetrator. Police officers provide an understanding of the law against perpetrators and victims of the criminal acts of fights as well as provide a detailed explanation of the benefits in the event of peace between the two sides. Moreover, the cause of the fight are things that are trivial. The Police should try to respond seriously to benefit all parties, since perpetrators and victims will also be fixed interact, because the victim and perpetrator resides in the same environment, together with the parents and families who are still on good terms with one another. INP seeks to guide, encourage, direct settlement of the case wisely in order to achieve objectives and obtain maximum results. The goal is the creation of security and public order dynamic.

- Lack of public awareness

Characteristics of communities in Blora backwardly compound, some have a high legal consciousness and what is also a society with a low legal awareness. For the youth, will easily ignited emotions when fights and fights will participate do if a friend or relative who was involved in a fight.

To overcome these obstacles, the National Police to provide guidance and counseling to the community and do against community leaders or religious figures. By 
cooperating with community leaders and religious leaders, they are expected to participate to provide guidance and counseling to youths from engaging in a fight / brawl.

Fostering community leaders aim to establish good relations with community leaders so willing to help the police in carrying out their duties are also in touch with the community itself. Mechanical or how its development through face to face, visits to provide information / information about the problems that are considered necessary, expressing congratulations on certain moments and offers help if known to require police assistance.

\section{Closing}

\subsection{Conclusion}

- The role of the police in handling and overcoming a fight between youth in realizing the public order in Blora is through the efforts of non penal (preventive) and attempts penal (repressive).

- Barriers arising in the treatment and prevention of fights between youth to realize the public order in Blora is the number of police personnel limited, the police difficult to present witnesses so that not all the perpetrators can be arrested, the third party to interfere in the settlement of the problem, and the lack of awareness Public. As a solution to overcome these obstacles is a Police officer attempted to appeal to the audience dangdut orchestra do not participate in the fight, investigators asking for information several people who could serve as witnesses to meet the criteria of sufficient preliminary evidence in the investigation process,

\subsection{Suggestion}

- The need for strengthening the role of community leaders, religious leaders, youth leaders, to anticipate a fight between youth especially in Blora.

- Necessary efforts to increase socialization and counseling about the legal awareness of the youth in particular public to prevent a fight between youth.

- Bhabinkamtibmas should always be active to provide guidance to citizens, especially in the month of fasting considering the number of dangdut orchestra in halal bi halal manner, to prevent a mass brawl.

\section{References}

[1] Barda Nawawi Arif, 2006, Masalah Penegakan Hukum dan Kebijakan Hukum Pidana dalam Penanggulangan Kejahatan, Bandung: Citra Aditya Bakti.

[2] Soerjono Soekanto, 1986, Faktor-Faktor yang Mempengaruhi Penegakan Hukum, Jakarta: Rineka Cipta.

[3] EM Soterio Maudoma, Use of Force In Together In Article 170 and Article 358 of the Criminal Code, Lex crimen, Vol.IV / 6 / Aug / 2015, p.67

[4] Act No. 2 of 2002 on the Indonesian police.

[5] Indonesian National Police Chief Regulation No. 14 of 2012 concerning the Crime Investigation Management. 